\title{
THE IMPORTANCE OF SOREDIATE CRUSTOSE LICHENS IN THE EPIPHYTIC LICHEN FLORA OF THE SWISS PLATEAU AND THE PRE-ALPS
}

\author{
Michael DIETRICH* and Christoph SCHEIDEGGER*
}

\begin{abstract}
Standardized lichen surveys were conducted on 849 trees in 132 ecological long-term observation plots in the Swiss Plateau and Pre-Alps: 262 lichen taxa were identified, $64(24 \%)$ of them sorediate crustose species. Their mean percentage of the flora on individual trees and in individual plots was even higher. The mean percentage of crustose lichen species with vegetative propagules, such as soredia, was per plot significantly higher in the Pre-Alps than in the Plateau, higher in forest than in non-forest areas, and, according to the vegetation belts, lowest in the colline-submontane zone. It was found that the biodiversity of lichens could not be determined without considering the sorediate crustose lichens. Furthermore, by performing standardized surveys of all taxa, the occurrence of the following species in Switzerland was confirmed for the first time: Cliostomum leprosum, Fuscidea arboricola, Fuscidea pusilla, Hypocenomyce leucococca, Hypocenomyce sorophora, Lecanora norvegica, Lepraria eburnea, Lepraria elobata, Lepraria jackii, Lepraria obtusatica, Lepraria rigidula, Pertusaria borealis and Rinodina griseosoralifera. Seven taxa that displayed distinctive chemistry, could not yet be identified.
\end{abstract}

C. 1996 The British Lichen Society

\section{Introduction}

The development of vegetative, symbiotic propagules is considered an evolutionary innovation of lichenized fungi (Honegger 1991; Poelt 1995; Büdel \& Scheidegger 1996). In general it is more frequent among lichens than generative dispersal (Henssen \& Jahns 1973). Evolutionary radiation of lichenized fungi often led to morphologically similar species that mainly differ in their types of diaspores (Hale 1965). Poelt (1970) compiled the numerous groups of forms in the concept of species pairs, where the fertile taxa are usually regarded as phylogenetically older. However, in addition to the known species pairs, there are many species without generative reproductive organs that could not be taxonomically allocated and thus so far are only tentatively identified or not at all. This is especially true of sorediate crustose lichens.

As a result of the difficulty in identification and the completely insufficient taxonomic classification within this circle of forms, floristic surveys have often paid too little attention to sorediate crustose lichens and their percentage of the total number of species could scarcely be estimated. In recent years numerous taxonomic studies have dealt with epiphytic sorediate crustose lichens (e.g. Tønsberg 1992; Diederich 1989; Laundon 1992; Leuckert \& Knoph 1992; Purvis et al., 1992; Schreiner \& Hafellner 1992) and have proved perfectly valid for other regions. Within the framework of the development of

*Swiss Federal Institute for Forest, Snow and Landscape Research $\mathrm{CH}-8903$ Birmensdorf, Switzerland. 


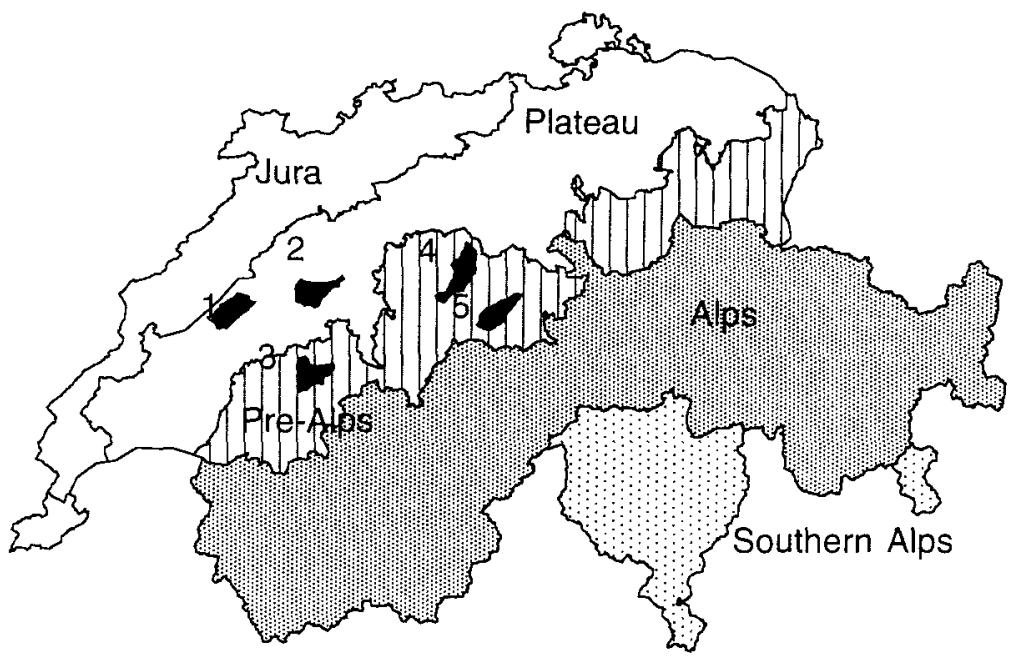

FIG. 1. The five areas of study on the Swiss Plateau and the Pre-Alps. 1: Payerne; 2: Bern West; 3: Schwarzsee; 4: Entlebuch; 5: Glaubenberg.

a representative survey of diversity, distribution and dynamics of the epiphytic lichens occurring in Switzerland, we attempted to identify all lichen species growing on the trunk of 849 randomly selected trees in order to determine the frequencies and percentages of sorediate crustose lichens.

\section{Materials and Methods}

The Plateau and Pre-Alps regions were chosen as the study area, comprising, respectively, $22.8 \%$ and $16.0 \%$ of the total area of Switzerland (41 $291 \mathrm{~km}^{2}$; Bundesamt für Statistik 1980). Within these regions data sampling was concentrated in the five areas Bern West, Entlebuch, Glaubenberg, Payerne and Schwarzsee (Welten \& Sutter 1982) (Fig. 1). The study area was stratified horizontally in terms of region, forest/non-forest, and vertically according to four vegetation belts (EAFV 1988). The criteria for stratification were combined, resulting in 12 large-scale habitats.

The entire epiphytic lichen flora of 849 trees from a stem height of 0 to $170 \mathrm{~cm}$ (sampling unit) was recorded as an assessment of the percentage of the stem covered (Dietrich 1993). The sampling units were situated in 132 ecological long-term observation plots located from the intersection points of the $1 \times 1 \mathrm{~km}$ grid of the Swiss co-ordinate system, which are taken as survey centres. In selecting the study plots, care was taken to ensure that at least ten were chosen for each of the 12 large-scale habitats. This resulted in the selection of 44 sampling plots in the Plateau and 88 in the Pre-Alps, 63 non-forest and 69 forest samples and 44 study sites in the collinesubmontane zone, 44 in the lower montane zone, 24 in the upper montane zone, and 20 in the subalpine zone.

For floristic assessment the lichenological data on each plot were compiled for one to 16 sampling units, depending on the density of the tree vegetation, in terms of presence or absence. If not otherwise noted, the results are based on this kind of plot data. On the basis of a subdivision of the study area according to the three stratification criteria, the dependence of the mean percentage of sorediate crustose lichens on region, forest/non-forest, and vegetation belt was examined. The given percentages per stratum were computed and the differences between them checked for significance by means of the $z$-test $(\alpha=1 \%$; Riedwyl 1978). We also checked the dependence between the percentage of sorediate crustose lichens and the total number of species.

All species were classified as 'sorediate crustose lichens' that, as a rule, produced soredia, independent of whether or not they also had organs for generative propagation. In accordance 
with Tonsberg (1992) we also considered Candelariella xanthostigma, Chaenotheca furfuracea and the species belonging to the genus Lepraria.

The identification of lichen substances was conducted within the standardized method after Culberson \& Ammann (1979). The material was not tested for chloroatranorin and isousnic acid. Several critical species were compared with the material identified by Tonsberg from the Herbarium Bergen (BG). The collections are presently stored in the herbarium of $M$. Dietrich. The nomenclature follows Santesson (1993).

\section{Results}

\section{Frequency of sorediate crustose lichens and their percentage of the lichen flora}

According to the stratification applied, the 132 sample sites investigated displayed differences in their ecology, as various types of vegetation with, for example differing exposures, inclinations and types of management occurred within each stratum. Within the entire study area 262 lichen taxa were found, 64 of them sorediate crustose lichens. In absolute terms their frequencies on 132 sample sites differed greatly (Table 1). Only $45 \%$ of the sorediate species (29) occurred on more than $5 \%$ of all the sample sites. The most frequent were Lepraria lobificans (found on 90 sites), Phlyctis argena (83), Micarea prasina (68), Candelariella xanthostigma (66), Lepraria rigidula (64) and Chaenotheca furfuracea (54). On the other hand, the species Biatora epixanthoides, Cliostomum leprosum, Fuscidea arboricola, Hypocenomyce scalaris, Lecidella scabra, Megalospora tuberculosa, Micarea sp. 1, Mycoblastus alpinus, Ochrolechia microstictoides, Pertusaria borealis, Pertusaria hemisphaerica and s.K. 3 were found only once.

Comparison of the mean percentage of sorediate crustose lichens between the strata (Table 2) reveals significant differences $(\alpha=1 \%)$. In the Pre-Alps the percentage of $34 \%$ is significantly higher than that of $27 \%$ in the Plateau. The same is true for the forest sites, the average of $37 \%$ being significantly higher than the $26 \%$ of the non-forest sites. Regarding the vegetation belts, the percentage in the colline-submontane zone, with only $25 \%$, is significantly lower than elsewhere. Within the sorediate crustose lichens, species of the genus Lepraria play an important role. They represent an average of $12 \%$ of the flora of the forest plots. This is significantly greater than the $5 \%$ they represent in the non-forest sites. Comparison of the mean percentage of Lepraria species per plot between the Plateau and Pre-Alps regions and between the vegetation belts reveals a higher value for the Pre-Alps and the lowest for the colline-submontane zone, but the differences are not significant. However, the significant differences between the mean percentages of sorediate crustose lichens in forest and non-forest, Plateau and Pre-Alps, colline-submontane and higher zones were not only due to the contribution of Lepraria alone. Also if Lepraria is excluded from the calculation, the differences are statistically significant: in forest sites the mean is $25 \%$, in non-forest $21 \%$; in the Pre-Alps 25\%, in the Plateau 19\%; and in the colline-submontane zone $19 \%$ (Table 2 ).

The number of lichen species exerts little negative effect on the percentage of sorediate crustose lichens. With a correlation coefficient of $r=-0.27$ the relationship is very low. The correlation between the total number of species 
TABLE 1. Sorediate crustose lichens in order of the number of sampling sites at which they were found

\begin{tabular}{|c|c|c|c|}
\hline Taxon & No. of sites & Taxon & No. of sites \\
\hline Lepraria lobificans & 90 & Haematomma ochroleucum & 5 \\
\hline Phlyctis argena & 83 & Lecanora allophana f. sorediata & 5 \\
\hline Micarea prasina & 68 & Trapelia corticola & 5 \\
\hline Candelariella xanthostigma & 66 & Lecidea porphyrospoda ${ }^{\star}$ & 4 \\
\hline Lepraria rigidula & 64 & Biatora efflorescens & 3 \\
\hline Candelariella reflexa & 54 & Trapeliopsis flexuosa & 3 \\
\hline Chaenotheca furfuracea & 36 & Caloplaca citrina & 2 \\
\hline Lecidella sp. $1^{\star \star}$ & 30 & Caloplaca obscurella & 2 \\
\hline Loxospora elatina & 29 & Megalaria pulverea & 2 \\
\hline Lecidella flavosorediata & 29 & Fuscidea praeruptorum ${ }^{\star}$ & 2 \\
\hline Ochrolechia androgyna & 27 & Fuscidea pusilla & 2 \\
\hline Pertusaria amara & 26 & Hypocenomyce leucococca ${ }^{\star}$ & 2 \\
\hline Lepraria eburnea & 26 & Lecanora conizaeoides & 2 \\
\hline Mycoblastus fucatus & 23 & Lecanora sp. $1^{\star \star}$ & 2 \\
\hline Buellia griseovirens & 22 & Lecanora impudens & 2 \\
\hline Pertusaria albescens & 22 & Lecanora norvegica & 2 \\
\hline Lecanora expallens & 21 & Ochrolechia alboflavescens & 2 \\
\hline Lecidella $\mathrm{sp} .2^{\star \star}$ & 21 & Ochrolechia arborea & 2 \\
\hline Lecanora aff. flavoleprosa $a^{\star \star}$ & 20 & Ochrolechia sp. $1^{\star \star}$ & 2 \\
\hline Lepraria elobata & 20 & Rinodina griseosoralifera ${ }^{\star}$ & 2 \\
\hline Chrysothrix candelaris & 19 & Biatora epixanthoides & 1 \\
\hline Hypocenomyce sorophora ${ }^{\star}$ & 13 & Cliostomum leprosum ${ }^{\star}$ & 1 \\
\hline Lepraria incana & 13 & Fuscidea arboricola ${ }^{\star}$ & 1 \\
\hline Lepraria obtusatica & 13 & Hypocenomyce scalaris & 1 \\
\hline Caloplaca chlorina & 10 & Lecidella scabra & 1 \\
\hline Biatora gyrophorica & 9 & Megalospora tuberculosa & 1 \\
\hline Leproloma vouauxi $i^{\star}$ & 9 & Micarea sp. $1^{\star \star}$ & 1 \\
\hline Ropalospora viridis & 8 & Mycoblastus alpinus* & 1 \\
\hline Lepraria jackii ${ }^{\star}$ & 8 & Ochrolechia microstictoides & 1 \\
\hline Lecidea nylanderi ${ }^{\star}$ & 6 & Pertusaria borealis ${ }^{\star}$ & 1 \\
\hline Lecidea pullata & 6 & Pertusaria hemisphaerica & 1 \\
\hline Trapeliopsis gelatinosa & 6 & s.K. $3^{\star \star}$ & 1 \\
\hline
\end{tabular}

* Species discussed in Appendix 1.

$\star \star$ Taxa discussed in Appendix 2.

and the percentage of Lepraria species is given by $r=-0.37$, that between the number of species and the percentage of sorediate crustose lichens excluding Lepraria by $r=-0 \cdot 10$. The highest percentage of sorediate crustose lichens in the 12 large-scale habitats was found in the forest areas of the lower montane zone of the Plateau with $43 \%$ (not significant; $n=10$ ); the lowest, with $17 \%$ (not significant, $n=13$ ), in the non-forest areas of the colline-submontane zone of the Plateau.

Sorediate crustose lichens constituted $24 \%$ of the lichen flora within the study area (Table 3). An average of 24 lichen species were found on each sampling plot $(n=132)$. The computed percentage of sorediate crustose lichens per plot was $32 \%$. In relation to the sampling unit $(n=849)$, with an average of ten lichen species, the computed percentage amounts to as much as $40 \%$ per individual tree. 
TABLE 2. Absolute and mean number of species per stratum and percentage of sorediate crustose lichens including (incl.) or excluding (excl.) Lepraria

\begin{tabular}{|c|c|c|c|c|c|}
\hline \multirow[b]{3}{*}{ Stratum } & & & \multicolumn{2}{|c|}{ Sorediate crustose lichens } & \multirow[b]{3}{*}{$n$} \\
\hline & \multicolumn{2}{|c|}{ Lichens } & incl. Lepraria & excl. Lepraria & \\
\hline & Total & $\varnothing$ & $\varnothing \%$ & $\varnothing \%$ & \\
\hline Non-forest & 195 & $25 \pm 9$ & $26 \pm 10$ & $21 \pm 7$ & 63 \\
\hline Forest & 202 & $23 \pm 11$ & $37 \pm 12$ & $25 \pm 9$ & 69 \\
\hline Colline-submontane zone & 141 & $22 \pm 8$ & $25 \pm 12$ & $19 \pm 9$ & 44 \\
\hline Lower montane zone & 145 & $20 \pm 9$ & $35 \pm 14$ & $24 \pm 9$ & 44 \\
\hline Upper montane zone & 160 & $30 \pm 12$ & $37 \pm 9$ & $27 \pm 6$ & 24 \\
\hline Subalpine zone & 114 & $30 \pm 9$ & $32 \pm 7$ & $24 \pm 5$ & 20 \\
\hline Plateau & 134 & $20 \pm 10$ & $27 \pm 13$ & $19 \pm 9$ & 44 \\
\hline Pre-Alps & 243 & $26 \pm 10$ & $34 \pm 12$ & $25 \pm 8$ & 88 \\
\hline
\end{tabular}

TABLE 3. Number of species and percentage of sorediate crustose lichens per study area, sampling plot and sampling unit *

\begin{tabular}{lccccc}
\hline & \multicolumn{2}{c}{ Lichens } & & \multicolumn{2}{c}{ Sorediate crustose lichens } \\
Interpretation unit & $\varnothing$ & & $\varnothing$ & $\varnothing \%$ & $n$ \\
\hline Study area & 262 & & 64 & 24 & 1 \\
Sampling plot & $24 \pm 10$ & & $8 \pm 3$ & $32 \pm 13$ & 132 \\
Sampling unit & $10 \pm 6$ & & $4 \pm 2$ & $40 \pm 23$ & 849 \\
\hline
\end{tabular}

$\star \varnothing=$ mean number of species \pm standard deviation; $\varnothing \%=$ mean percentage \pm standard deviation; $n=$ sample size.

\section{Discussion}

Thanks to better knowledge of sorediate crustose lichens achieved through numerous new descriptions and revisions over the past few years, it was possible to identify 64 sorediate crustose lichens in the Swiss Plateau and Pre-Alps. This number constitutes $24 \%$ of the total 262 species distinguished. A systematic survey of 849 sample units as tree trunks on 132 study plots revealed the high percentage of sorediate crustose lichens among the flora, and allowed the discovery of new or otherwise interesting species to Switzerland (Appendix 1 and 2). Furthermore, sampling from plots distributed over diverse habitats, according to the vertical and horizontal stratification of the whole study area, permitted probable conjectures on the distribution and frequency of species of which little is known so far. For instance, Lepraria lobificans and Lepraria rigidula were found to be just as common and widely distributed within the study area as such well-known sorediate crustose species as Phlyctis argena or Micarea prasina. In contrast, Lepraria obtusatica seems to be a stenoecious species favouring fir-beech and fir-spruce forests in the 
montane and subalpine zones. Also, just because a particular species has not been identified in an area does not necessarily imply that it is uncommon. For instance, Lecidella sp. 1 was found only in the Pre-Alps, yet on 30 sampling sites at all altitudes; Lecidella sp. 2, on the other hand occurred throughout the entire study area, except in the subalpine zone.

The distribution of frequency indicates that there are few common species such as Lepraria lobificans and numerous rare ones, occurring at a percentage of only one or a few per thousand host trees. Thus it is comparable to the overall frequency distribution of lichens as described by Kuusinen (1994), Roth (1995) and Dietrich (1996). From this it is clear that there are rare species amongst sorediate crustose lichens but they can be investigated by means of an efficient survey method.

Crustose lichens reproducing by soredia do not comprise the same percentage in all habitats. They occur significantly more frequently in forested areas than in non-forested areas. Also the percentage of Lepraria species, as sorediate crustose lichens (Tønsberg 1992), is significantly higher in forests. This is easily understandable, as the leprose growth form, with its hydrophobic thallus surface (Henssen \& Jahns 1973), can be regarded as an adaptation to the absorption of water vapour, and is commonly found on sheltered sites with high humidity and little illumination (Tønsberg 1992). In the other sorediate lichens, the formation of soredia is regarded as an advantageous propagation strategy of $k$-selected species (Rogers 1990). Since the mean percentage of sorediate crustose lichens, even if Lepraria is excluded, is significantly higher in forest stands than on solitary trees, this strategy seems to be more important in forests.

Just how the significantly higher percentage in the Pre-Alps as opposed to the Plateau is to be interpreted needs further studies, as it could be assumed that the more intensive land-use in the Plateau on the whole promotes $k$-selected species. The same is true for the colline-submontane zone, which, within the study area, bears the lowest percentage of sorediate crustose lichens, but the probable highest in terms of intensity of land use.

Sites with few lichens are often colonized only by sorediate crustose species, such as Lepraria lobificans, L. rigidula and Micarea prasina. Therefore, it may be expected that the percentage of sorediate crustose species is negatively affected by the total number of species. In fact, however, the correlation, with $r=-0 \cdot 27$, is very low. Furthermore, on the basis of the low correlation coefficient of $r=-0.37$ between number of species and percentage of Lepraria species, the hypothesis that sampling sites with few species display a high percentage of ubiquitous Lepraria species can be dismissed. The negative correlation of the number of species to the percentage of sorediate crustose lichens excluding Lepraria is only $r=-0 \cdot 10$.

The recognition of sorediate lichens in the field and the essential analysis by thin-layer chromatography (TLC) in the laboratory consume much time and material. Furthermore, the risk of faulty identification is undoubtedly higher if sorediate crustose lichens are considered in a survey. However, the percentage of species in the study area as a whole $(24 \%)$, the mean value for the sampling sites $(32 \%)$ and the trees $(40 \%)$ justify the expenditure for the determination of all taxa. In terms of biodiversity, floristic lichen surveys that do not include 
sorediate crustose lichens are incomplete. Consequently the aims of any given survey should be examined to determine whether these taxa can justifiably be omitted. Possibly their inclusion could be of use for gaining further knowledge on the diversity, pattern and dynamics of epiphytic lichen vegetation.

The authors wish to express their thanks to $M$. Sieber (Birmensdorf) for translating the manuscript. Our sincerest thanks go to $\mathrm{Dr} \mathrm{T}$. Tønsberg for giving us access to material for comparison from Herbar BG and to Dr B. Coppins (Edinburgh) for the comments on a sterile species of Micarea and several fertile crustose lichens; also to Prof. C. Leuckert (Berlin) for analysing the compounds contained in two unidentified species, and Dr P. Diederich for giving us access to his species lists from excursions in Switzerland. Stimulating discussions with Dr P. Brassel, Prof. R. Schlaepfer and R. Ghosh (Birmensdorf), Dr K. Ammann and B. Fischer (Berne) are gratefully acknowledged. We are also grateful to the Swiss National Science Foundation for financial support (Project No. 31-32567.91).

\section{Appendix 1: New and interesting species to Switzerland}

The data are restricted to specimens investigated by means of TLC. The associated species include the lichens found on the corresponding tree trunks from $0-170 \mathrm{~cm}$. The data on distribution are based on the literature by Tønsberg (1992), Purvis et al. (1992), Diederich (1989), Santesson (1993), Clauzade \& Roux (1985), Nimis (1993), Schreiner \& Hafellner (1992), Poelt \& Vèzda $(1977,1981)$, and Wirth (1994).

\section{Cliostomum leprosum (Räsänen) Holien \& Tønsberg}

Pre-Alps: Canton of Obwalden, Sarnen, Trogenwald, Pinus mugo, 1516 m, Dietrich 2016.

Chemistry: Atranorin, caperatic acid.

Associated species: 13 species including Hypogymnia bitteri, H. farinacea, Parmeliopsis ambigua, P. hyperopta.

Distribution recorded in the literature: Finland, Norway, Sweden, North America; new to Switzerland.

\section{Fuscidea arboricola Coppins \& Tonsberg}

Pre-Alps: Canton of Lucerne, Escholzmatt, Schriberschwändili, Fagus sylvatica, 1058 m, Dietrich 1698.

Chemistry: Fumarprotocetraric acid, protocetraric acid, confumarprotocetraric acid.

Associated species: 8 species including Arthonia radiata, Buellia griseovirens, Graphis scripta, Melanelia fuliginosa.

Distribution recorded in the literature: Norway, Scotland, Sweden; new to Switzerland.

\section{Fuscidea praeruptorum (Du Rietz \& H. Magn.) V. Wirth \& Vězda}

Pre-Alps: Canton of Fribourg, Plaffeien, Eggersloch, Picea abies, $1210 \mathrm{~m}$, Dietrich 2165; Canton of Lucerne, Schüptheim, Eggli, Acer pseudoplatanus, $756 \mathrm{~m}$, Dietrich 1684.

Chemistry: Alectorialic acid with satellites.

Associated species: 10 and 27 species; common to both localities: Melanelia exasperatula, Parmelia sulcata.

Distribution (as epiphytes) recorded in the literature: Norway, Sweden. This species has primarily been found on saxicolous sites. Its distribution ranges from the British Isles over Scandinavia and western Europe to eastern Central Europe and southern Italy.

\section{Fuscidea pusilla Tonsberg}

Pre-Alps: Canton of Obwalden, Sarnen, Herrenboden, Abies alba, $1299 \mathrm{~m}$, Dietrich 2006; Fengmoo, Picea abies, $1127 \mathrm{~m}$, Dietrich 2011.

Chemistry: Divaricatic acid.

Associated species: 13 species each; common to both localities: Hypogymmia physodes, Lepraria lobificans, Micarea prasina.

Distribution recorded in the literature: Denmark, Germany, Norway, Scotland, Sweden; new to Switzerland. 
Hypocenomyce leucococca R. Sant.

Pre-Alps: Canton of Obwalden, Giswil, Rorwald, Acer pseudoplatanus, 1250 m, Dietrich 1602. Chemistry: Alectorialic acid with satellites.

Associated species: 18 species including Loxospora elatina, Parmelia saxatilis, Parmeliopsis ambigua, Pertusaria amara, Periusaria borealis.

Distribution recorded in the literature: Austria, Finland, Norway, Scotland, Sweden, North America; new to Switzerland.

\section{Hypocenomyce sorophora (Vain.) P. James \& Poelt}

Pre-Alps: Canton of Obwalden, Giswil, four sites between 1322 and $1553 \mathrm{~m}$, Abies alba, Picea abies, Pinus mugo, Dietrich 1614, 1635, 1645, 2035; Samen, 2 sites at 1409 and $1516 \mathrm{~m}$, Picea abies, Pinus mugo, Dietrich 1953, 1968.

Chemistry: Alectorialic acid with satellites, \pm traces of atranorin.

Associated species: 7 to 22 (13 on average); occurring more than four times: Hypogymnia physodes, Imshaugia aleurites, Parmeliopsis ambigua, Platismatia glauca, Pseudevernia furfuracea.

Distribution recorded in the literature: Austria, England, Germany, Italy, Norway, Sweden, North America; new to Switzerland.

Further observations on Hypocenomyce sorophora in thinned conifer stands and on solitary conifers in the subalpine zone indicate that this species is not uncommon, at least in the upper part of the Pre-Alps.

Lecanora allophana Nyl. f. sorediata Nyl. ex Vain.

Plateau: Canton of Fribourg, Rueyres-les-Prés, fuglans regia, $490 \mathrm{~m}$, Dietrich 1494; Pre-Alps: Canton of Lucerne, Schüpfheim, Eggli, Acer pseudoplatanus, 756 m, Dietrich 1682.

Chemistry: Atranorin, allophana unknown 1 and 2 (Tønsberg 1992). Parallel chromatography of Lecanora allophana f. sorediata and L. impudens revealed the varying pattern of triterpenes (Tønsberg 1992).

Associated species: 20 and 27 species; common to both localities: Candelaria concolor, Candelariella xanthostigma, Lecanora migosella, Lecanora sambuci, Lecidella flavosorediata, Melanelia subargentifera, Phaeophyscia orbicularis, Physcia adscendens, $P$. tenella, Xanthoria parientina; in Rueyres-les-Prés only, Lecanora allophana f. allophana.

Distribution recorded in the literature: Northern and Central Europe.

\section{Lecanora norvegica Tonsberg}

Pre-Alps: Canton of Lucerne, Entlebuch, Dieplischwand, Abies alba, $947 \mathrm{~m}$, Dietrich 1677; Canton of Obwalden, Giswil, Glaubenbielental, Acer pseudoplatanus, $1322 \mathrm{~m}$, Dietrich 1612.

Chemistry: Atranorin, fumarprotocetraric acid, protocetraric acid. Fumarprotocetraric acid was not reported from Norwegian specimens (Tonsberg 1992).

Associated species: 7 and 22 species; common to both localities: Hypogymnia farinacea, H. physodes, Lepraria rigidula, Loxospora elatina, Micarea prasina.

Distribution recorded in the literature: Norway, Sweden; new to Switzerland.

Lecidea nylanderi (Anzi) Th. Fr.

Pre-Alps: Canton of Obwalden, Sarnen, Siwellenbrunnenwald, Picea abies, $1333 \mathrm{~m}$, Dietrich 1930.

Chemistry: Divaricatic acid, trace of atranorin.

Associated species: 25 species including Buellia schaereri, Calicium viride, Evernia divaricata, Loxospora elatina, Mycoblastus affinis, $M$. fucatus.

Distribution recorded in the literature: Europe, North America.

As with Hypocenomyce sorophora, Lecidea nylanderi was frequently observed in both the subalpine and the upper montane zones of the Pre-Alps, usually in clusters or loosened stands of conifers.

Lecidea porphyrospoda (Anzi) Th. Fr.

Pre-Alps: Canton of Lucerne, Entlebuch, Dieplischwand, Abies alba, $947 \mathrm{~m}$, Dietrich 1676; Canton of Obwalden, Sarnen, Grund, Alnus incana, $1311 \mathrm{~m}$, Dietrich 2005.

Chemistry: Lobaric acid.

Associated species: 7 and 32 species; common to both localities: Hypogymnia physodes, Lepraria rigidula.

Distribution recorded in the literature: Central Europe, Italy, Norway, Sweden. 


\section{Lepraria eburnea J. R. Laundon}

Pre-Alps: Canton of Lucerne, Doppelschwand, Oberhüseren, Picea abies, $700 \mathrm{~m}$, Dietrich 1829; Romoos, Chrummatt, Acer pseudoplatanus, 942 m, Dietrich 2091; Canton of Obwalden, Giswil, Hackerenboden, Picea abies, $950 \mathrm{~m}$, Dietrich 1859; Sarnen, five sites between 598 and $1423 \mathrm{~m}$, Picea abies, Dietrich 1813, 1959, 1961, 1979, 1996.

Chemistry: Alectorialic acid, barbatolic acid, protocetraric acid, \pm atranorin.

Associated species: 4 to 22 (11 on average); occurring more than four times: Chaenotheca furfuracea, C. trichialis, Dimerella pineti, Lepraria lobificans, Micarea prasina.

Distribution recorded in the literature: British Isles, France, Germany, Norway, Sweden, North America; new to Switzerland.

Numerous other observations in the Pre-Alps indicate that this species is widespread and common, at least in this region.

\section{Lepraria elobata Tonsberg}

Pre-Alps: Canton of Lucerne, Escholzmatt, Schriberschwändili, Picea abies, $1058 \mathrm{~m}$, Dietrich 1701; Schüpfheim, Chrachenwald, Picea abies, $1014 \mathrm{~m}$, Dietrich 1681; Canton of Obwalden, Giswil, Seli, Picea abies, 1453 m, Dietrich 1947; Sachseln, Grossmattwald, 544 m, Dietrich 2063; Sarnen, 4 sites between 1311 and 1578 m, Alnus incana, Picea abies, Dietrich 1884, 1923, 1964, 1973.

Chemistry: Atranorin, stictic acid with satellites, zeorin.

Associated species: 3 to 25 (17 on average); occurring more than four times: Chaenotheca chrysocephala, Cladonia coniocraea, Hypogymnia physodes, Imshaugia aleurites, Parmeliopsis ambigua, Pseudevernia furfuracea.

Distribution recorded in the literature: British Isles, Germany, Norway, Sweden; new to Switzerland.

As in the case of Lepraria ebumea, this species was observed several times in other places, which indicates that it is widely distributed and relatively common.

\section{Lepraria jackii Tonsberg}

Plateau: Canton of Berne, Frauenkappelen, Ägerten, Pseudotsuga menziesii, $651 \mathrm{~m}$, Dietrich 2110 ; Pre-Alps: Canton of Obwalden, Giswil, Glaubenbielen, Picea abies, $1553 \mathrm{~m}$, Dietrich 2027; Sarnen, five sites between 1245 and $1316 \mathrm{~m}$, Abies alba, Picea abies, Pinus mugo, Dietrich 1669, $1905,1969,1978,1993$.

Chemistry: Atranorin, roccellic acid, rangiformic acid.

Associated species: 6 to 34 (17 on average); occurring more than four times: Chaenotheca chrysocephala, Cladonia digitata, Hypogymnia physodes, Imshaugia aleurites, Lepraria lobificans, Ochrolechia androgyna, Parmelia saxatilis, Parmeliopsis ambigua, Pseudevernia furfuracea.

Distribution recorded in the literature: British Isles, Germany, Norway, Sweden; new to Switzerland. Lepraria jackii seems to be less widely distributed than L. eburnea or L. elobata. Observations in the upper montane and subalpine zones of the Pre-Alps, however, indicate that this species is not uncommon in these areas.

\section{Lepraria obtusatica Tønsberg}

Pre-Alps: Canton of Lucerne, Romoos, Alpetliweid, Picea abies, 785 m, Dietrich 1837.

Chemistry: Obtusatic acid, barbatic acid.

Associated species: Dimeralla pineti, Lepraria lobificans, Micarea prasina.

Distribution recorded in the literature: Norway; new to Switzerland.

Lepraria obtusatica has been observed exclusively in the Pre-Alps, where it mainly occurs in semi-natural fir-beech and fir-spruce forests on Abies alba and Picea abies.

\section{Lepraria rigidula (de Lesd.) Tonsberg}

Plateau and Pre-Alps in the cantons of Berne, Fribourg, Lucerne, Obwalden, Waadt, 15 sites between 433 and $1534 \mathrm{~m}$, Abies alba, Acer pseudoplatanus, Fagus sylvatica, Fraxinus excelsior, Juglans regia, Picea abies, Populus tremula, Prunus avium, Pyms communis, Salix sp., Dietrich 1438, $1462,1474,1478,1584,1657,1680,1702,1747,1795,1868,1940,1945,1975,1982$.

Chemistry: Atranorin, rigidula unknown (Tønsberg 1992).

Associated species: 2 to 26 (11 on average); occurring more than four times: Candelariella reflexa, Hypogymnia physodes, Lepraria lobificans, Micarea prasina, Phlyctis argena, Physcia tenella. 
Distribution recorded in the literature: Andorra, Belgium, British Isles, Germany, Luxembourg, Norway, Spain, Sweden, new to Switzerland.

Apart from Lepraria lobificans, L. rigidula is the most common Lepraria species observed in both the Plateau and the Pre-Alps.

\section{Leproloma vouauxii (Hue) J. R. Laundon}

Plateau and Pre-Alps in the cantons of Berne, Fribourg, Lucerne, Waadt, eight sites between 463 and $767 \mathrm{~m}$; Acer pseudoplatanus, Crataegus sp., Fraxinus excelsior, Malus sylvestris, Prumus avium, Pyrus communis, Quercus robur, Dietrich 1464, 1500, 1685, 2101, 2102, 2124, 2134, 2155.

Chemistry: Pannaric acid-6-methylester, vouauxii unknown 1 and 2 (Tønsberg 1992).

Associated species: 8 to 27 (17 on average); occurring more than four times: Candelariella xanthostigma, Lecanora carpinea, L. sambuci, Phlyctis argena, Physcia tenella, Xanthoria parietina.

Distribution recorded in literature: Widespread over both hemispheres.

Mycoblastus alpinus (Fr.) Th. Fr. ex Hellb.

Pre-Alps: Canton of Obwalden, Giswil, Loomettlen, Picea abies, $1357 \mathrm{~m}$, Dietrich 1650.

Chemistry: Atranorin, planaic acid, usnic acid.

Associated species: 16 species including Chaenotheca chrysocephala, Hypogymmia bitteri, Micarea peliocarpa, Parmelia saxalitis, Usnea subfloridana.

Distribution recorded in the literature: Northern Europe, England, Germany, Scotland, Switzerland.

\section{Pertusaria borealis Erichsen}

Pre-Alps: Canton of Obwalden, Giswil, Rorwald, Acer pseudoplatanus, $1250 \mathrm{~m}$, Dietrich 1601.

Chemistry: Fumarprotocetraric acid.

Associated species: 18 species including Hypocenomyce leucococca, Loxospora elatina, Pammelia saxatilis, Pameliopsis ambigua, Pertusaria amara.

Distribution recorded in the literature: Finland, Norway, Sweden, possibly Scotland, North America; new to Switzerland.

\section{Rinodina griseosoralifera Coppins}

Pre-Alps: Canton of Obwalden, Giswil, Brunegg, Acer pseudoplatanus, 992 m, Dietrich 1862.

Chenistry: Atranorin, zeorin.

Associated species: 32 species including Leptogium satuminum, L. teretiuscultum, Pamelina pastillifera, Peltigera praetextata, Phlyctis argena, Physcia tenella.

Distribution recorded in the literature: Austria, British Isles, France, Germany, Luxembourg, Norway; new to Switzerland.

\section{Appendix 2: Unidentified sorediate crustose lichens}

Seven species with distinct chemistry could not be identified. They are briefly annotated with working names. Speciments analysed by TLC are cited. None of them exhibited generative organs of propagation.

Lecanora aff. flavoleprosa seems morphologically identical with Lecanora flacoleprosa, but contains only usnic acid and zeorin as secondary lichen substances.

Plateau and Pre-Alps: In the cantons of Berne, Fribourg, Lucerne, Obwalden, Waadt, eight sites between 430 and $1245 \mathrm{~m}$, Picea abies, Pinus sylvestris, Salix alba, Dietrich 1660, 1712, 1730, 1737, $1836,1850,2018,2138$.

Lecanora sp. 1 exhibits an endo- to thin episubstratal whitish thallus, soon breaking down into whitish to sulphur-coloured irregular soralia. The compounds it contains are fumarprotocetraric acid, usnic acid and zeorin. Specimens for further identification are with P. James (London). Pre-Alps: Canton of Obwalden, Sarnen, Münchenboden, Abies alba, $1299 \mathrm{~m}$, Dietrich 2010.

Lecidella sp. 1 displays an endo- to episubstratal thallus, which is areolated in patches, and forms irregular grey-green to green soralia. C. Leuckert (Berlin) found the compounds atranorin, arthothelin (with a trace of dichlornorlichenxathone), thiophanic acid and a trace of another compound that he could not identify (written communication). 
Pre-Alps: In the cantons of Berne, Fribourg, Lucerne, Obwalden, ten sites between 947 and 1398 m, Abies alba, Picea abies, Dietrich 1610, 1679, 1683, 1697, 1703, 2012, 2017, 2075, 2077, 2087.

Lecidella sp. 2 displays an endo- to thin episubstratal, whitish thallus, which is irregularly bursting to form grey-green soralia. C. Leuckert identified the compounds atranorin, capistratone, isoarthothelin, \pm thiophanic acid, $\pm 3-\mathrm{O}$-methylthiophanic acid, \pm aotearone (written communication). Specimens for the identification of Lecidella sp. 1 and Lecidella sp. 2 are with C. Leuckert.

Plateau and Pre-Alps: In the cantons of Berne, Lucerne, Obwalden, Waadt, eight sites between 433 and $980 \mathrm{~m}$, Acer pseudoplatanus, Fagus sylvatica, Fraxinus excelsior, Populus tremula, Prunus domestica, Dietrich 1481, 1589, 1704, 1706, 1714, 1719, 2037, 2142.

Micarea sp. 1 displays a mostly endosubstratal to gelatinous, grey to blue-green irregularly sorediate thallus. It has been shown to contain gyrophoric acid. The only specimen was identified by B. Coppins (Edinburgh) as probably a new species of the genus Micarea.

Pre-Alps: Canton of Obwalden, Sarnen, Rischiwald, Picea abies, 1033 m, Dietrich 2015.

Ochrolechia sp. 1 is clearly episubstratal with a relatively thick, areolated, whitish thallus that displays pale green soralia, first punctiform, later becoming confluent. A brown prothallus can be clearly observed. The only compound found was an unidentified xanthone (Rf classes 7-7-7).

Plateau: Canton of Berne, Mühleberg, Buech, Fuglans regia, $636 \mathrm{~m}$, Dietrich 2107; Pre-Alps: Canton of Obwalden, Sarnen, Grund, Alnus incana, $1311 \mathrm{~m}$, Dietrich 1891.

s.K. 3 is endo- to episubstratal, with a thin, pale green, finely sorediate thallus. It was found to contain two unidentified xanthones.

Pre-Alps: Canton of Obwalden, Sachseln, Eschlenwald, Fraximus excelsior, 532 m, Dietrich 2055.

\section{REFERENCES}

Büdel, B. \& Scheidegger, C. (1996) Thallus morphology and anatomy. In Lichen Biology (T. H. Nash III, ed.): 37-64. Cambridge: Cambridge University Press.

Bundesamt für Statistik (ed.) (1980) Informationsraster Benützerhandbuch. Arbeitsdokumente schavizerische Statistik (Bern) H. 3.

Clauzade, G. \& Roux, C. (1985) Likenoj de Okcidenta Europo. IIustrita determinlibro. Bulletin de la Société Botanique du Centre-Ouest. Nouvelle série- Numéro Spécial 7: 1-893.

Culberson, C. F. \& Ammann, K. (1979) Standardmethode zur Dünnschichtchromatographie von Flechtensubstanzen. Herzogia 5: 1-24.

Diederich, P. (1989) Les lichens épiphytiques et leurs champignons lichénicoles (macrolichens exceptés) du Luxembourg. Travaux Scientifiques du Musée National d'Histoire Naturelle de Luxembourg 14: 1-268.

Dietrich, M. (1993) Methodenentwicklung für eine standardisierte Inventarisierung der epiphytischen Flechten im Schweizerischen Mittelland und den Voralpen. Meylania 4: 19-20.

Dietrich, M. (1996) Häufigkeit, Diversität, Verbreitung und Dynamik von epiphytischen Flechten im Schweizerischen Mittelland und den Voralpen. Methodische Ansätze zur Erstellung einer Roten Liste und zur standardisierten Durchführung von Dauerbeobachtungen. Doctoral Thesis, University Bern.

EAFV (Eidgenössische Anstalt für das forstliche Versuchswesen) und BFL (Bundesamt für Forstwesen und Landschaftsschutz) (eds) (1988) Schweizerisches Landesforstinventar: Ergebnisse der Erstaufnahmen 1982-1986. Berichte der Eidgenössischen Anstalt für das forstliche Versuchszesen 305: 1-375.

Hale, M. E. (1965) A monograph of Parmelia subgenus Amphigynnia. Bulletm of the United States National Museum, Contributions from the United States National Herbarium 36: 193-357.

Henssen, A. \& Jahns, H. M. (1973) ["1974"] Lichenes. Stuttgart: Georg Thieme Verlag.

Honegger, R. (1991) Fungal evolution: Symbiosis and morphogenesis. In Symbiosis, a source of eiolutionary innovation (L. Margulis \& R. Fester, eds): 319-340. Cambridge, MA: MIT Press.

Kuusinen, M. (1994) Epiphytic lichen diveristy on Salix caprea in old-growth southern and middle boreal forests of Finland. Annales Botanici Fennici 31: 77-92. 
Laundon, J. (1992) Lepraria in the British Isles. Lichenologist 24: 315-350.

Leuckert, C. \& Knoph, J. G. (1992) European taxa of saxicolous Lecidella containing chloroxanthones: identification of pattern using thin layer chromatography. Lichenologist 24: 383-397.

Nimis, P. L. (1993) The Lichens of Italy. An annotated catalogue. Torino: Museo regionale di scienze naturali.

Poelt, J. (1970) Das Konzept der Artenpaare bei den Flechten. Berichte der Deutschen Botanischen Gesellschaft. 4: 77-81.

Poelt, J. (1995) On lichenized asexual diaspores in foliose lichens-a contribution towards a more differentiated nomenclature (Lichens, Lecanorales). Cryptogamic Botany 5: 159-162.

Poelt, J. \& Vězda, A. (1977) Bestimmungsschlüssel europäischer Flechten. Ergänzungsheft I. Vaduz: J. Cramer.

Poelt, J. \& Vězda, A. (1981) Bestimmungsschlüssel europäischer Flechten. Ergänzungsheft II. Vaduz: J. Cramer.

Purvis, O. W., Coppins, B. J., Hawksworth, D. L., James, P. W. \& Moore, D. M. (eds) (1992) The Lichen Flora of Great Britain and Ireland. London: The Natural History Museum.

Riedwyl, H. (1978) Angewandte mathematische Statistik in Wissenschaft, Administration und Technik. Bern: Paul Haupt.

Rogers, R. W. (1990) Ecological strategies of lichens. Lichenologist 22: 149-162.

Roth, I. (1995) Die Edelkastanie als Lebensraum für epiphytische Flechten. Lizentiatsarbeit Systematisch-Geobotanisches Institut, Universität Bern.

Santesson, R. (1993) The Lichens and Lichenicolous Fungi of Sweden and Norway. Lund.

Schreiner, E. \& Hafellner, J. (1992) Sorediöse, corticole Krustenflechten im Ostalpenraum. I. Die Flechtenstoffe und die gesicherte Verbreitung der besser bekannten Arten. Bibliotheca Lichenologica. 45: 1-291.

Tensberg, T. (1992) The sorediate and isidiate, corticolous, crustose lichens in Norway. Sommerfeltia 14: 1-331.

Welten, M. \& Sutter, R. (1982) Verbreitungsatlas der Farn- und Blütenpflanzen der Schweiz. Basel: Birkhäuser.

Wirth, V. (1994) Checkliste der Flechten und flechtenbewohnenden Pilze Deutschlands-eine Arbeitshilfe. Stuttgarter Beiträge zur Naturkunde. Serie A 517: 1-63.

Accepted for publication 1 October 1995 